\title{
Short Term Effect of He-Ne Laser on Jatropha curcas Leaf Development and Amino Acid Biosynthesis: More Insights in Developmental Genetics of Oil Producing Plants
}

\author{
Noha S. Khalifa" and Hatem El Ghandoor \\ Department of Botany and *Department of Physics, Faculty of Science, Ain Shams \\ University, Cairo, Egypt.
}

\begin{abstract}
TATROPHA curcas is a promising plant for biodiesel production. One tentative way to increase oil production is using non traditional physical methods such as laser. It had been shown before that laser could enhance plant growth and development as general. In this study, the DNA was extracted from leaves of plants grown from seeds collected from different regions in Egypt and tested using PCR to confirm their homogenousity. Then, the fully expanded leaves of Jatropha (6- week- old plants) were exposed to a dose equaling $300 \mathrm{~mJ} \mathrm{~cm}{ }^{-2}$ Helium-Neon $(\mathrm{He}-\mathrm{Ne})$ laser. The effect of the administered dose on the photosynthetic pigment expression, chloroplast biogenesis and total amino acid biosynthesis were evaluated after 0,1 and $24 \mathrm{~h}$ post irradiation. Laser treatment in this work did enhance all the previousely mentioned parametrs as will be discussed further in relation to the possibility of using laser as a novel protocol to enhance field crop plants as general.
\end{abstract}

Keywords: Laser, RAPD PCR, Chloroplast biogenesis, Amino acid, Developmental genetics in oil plants, Jatropha curcas .

\section{Introduction}

Jatropha curcas L. (Euphorbiacea) is a multipurpose plant with many considerable applications and merits. This tropical plant can be grown in semidry areas. It can be used for land reclaimation, as a hedge, and/ or for biodiesl production (Openshaw, 2000). Therefore, at the national level in Egypt, growing this plant could provide employment, improve the environment and enhance the quality of life. The plant seeds produce an eco-friendly and bio-degradable oil that can be used as a sustainable clean energy to substitute fuelwood and others. However, domestication of $J$. curcas under various climatic conditions is not fully documented. It is suggested that utraditional scientific methods and novel technologies should be applied to this plant in order to accelerate its productivity (Montes \& Melchinger, 2016). In our previously published work, we found that laser treatment resulted in a significant increase in the expression of Rubisco large subunit (RbcL) above the basal level in soybean seedlings (Khalifa \& Ghandoor, 2011) and $J$. curcas (Khalifa \& Elsherief, 2013). It is known that RbcL is de novo synthesized inside the chloroplast (Gutteridgel \& Gatenby, 1995).
Moreover, Xiaoling et al. (2013) mentioned that $\mathrm{He}-\mathrm{Ne}$ laser had apparent effect on repairing of the photosynthetic machinery of peanut seedlings damaged by enhanced UV-B radiation.

To determine if there is a correlation between $\mathrm{RbcL}$ overexpression and chloroplast biogenesis in response to laser treatment, we compared the ultrastructure of chloroplast and their count in the treated and the untreated $J$. curcas plants using Transmission Electron Microscopy (TEM). In this connection, chloroplasts are known as being not de novo synthesized, but instead are propagated from pre-existing plastids, according to a division machinery (Sakamoto et al., 2008). In addition, plastids are transmitted from generation to generation with a unique mode of inheritance, but the factors affecting this process are still needing further unravelling. In addition, chloroplasts are indispensable for plant development through achieving certain biochemical processes including the synthesis of pigments, amino acids, lipids, plant hormones and sensing environmental stimuli (Pogson et al., 2015).

Thus, the present work aimed to study chloroplast biogenesis, concomitant with the 
concentrations of different photosynthetic pigments and total amino acid contents, inresponse to laser treatment of $J$. curcas leaves. The results shown herein may further elucidate the role of laser light signal in increasing the photosynthesis rate as general in the plant under investigation.

\section{Materials and Methods}

\section{Plant material}

Jatropha plants were directly grown from seeds in 6 inch pots filled with 2:1 clay to sand soil. Seeds were collected from five different regions across Egypt (Al- Oksor, Aswan, Aborawash, Sekem farm and Red sea governorate). Plants were grown under green house condition in the botanical garden of Botany Department, Faculty of Science, Ain Shams University, Cairo, Egypt.

\section{DNA extraction}

DNA samples were extracted from fully expanded leaves of 6-week-old plants following the method of Chao et al. (2017). DNA was extracted from samples collected from previousely mentioned regions around Egypt and tested using PCR to confirm its homogenousity.

$P C R$ reaction and primers used

50 ng genomic DNA was used in PCR reaction as a template using conventional PCR machine (Techne, UK). All PCR components were purchased from Promega (Wisconscin, USA). Primers (Metabion International AG, Germany) used for these reactions are shown in Table 1. Primers were used either alone or as pairs to confirm the homogenousity of the collected samples. The PCR reaction components are shown in Table 2. The PCR condition is shown in Table 3.

TABLE 1. RAPD-PCR primers used for the genotyping of Jatropha plants.

\begin{tabular}{lcc}
\hline$\#$ & Primer name & Sequence \\
\hline 1 & R11 & CCAAGCAGT \\
2 & R34 & GTCACCGGA \\
3 & R38 & CTAGCCGAC \\
4 & R86 & CAAGGACAC \\
5 & r 1302.1 & GGAAATCGTG \\
6 & r1325.2 & CGGTAGTTGG \\
\hline
\end{tabular}

TABLE 2. Componentse in the PCR reaction mixture.

\begin{tabular}{lccccccc}
\hline Ingredient & DNA & Primer & $\begin{array}{c}\text { dNTPS } \\
\text { mix }\end{array}$ & $\mathbf{M g C l}_{2}$ & $\begin{array}{c}\text { Taq } \\
\text { polymerase }\end{array}$ & $\begin{array}{c}\text { Total reaction } \\
\text { volume }\end{array}$ \\
\hline Volume $(\mu \mathrm{l})$ & 3 & 1 & 2 & 4 & & 0.5 & \\
Concentration & $50 \mathrm{ng}$ & $100 \mathrm{pm}$ & $2.5 \mu \mathrm{M}$ & $5 \mathrm{x}$ & & 5 Units & 20 \\
\hline
\end{tabular}

TABLE 3. PCR reaction conditions.

\begin{tabular}{ccccccc}
\hline & Hot start & Uncoiling & Annealing & Extension & Post- extension & \# Cycles \\
\hline $\begin{array}{c}\text { Temperature } \\
\left({ }^{\circ} \mathrm{C}\right)\end{array}$ & 95 & 93 & 34 & 72 & 72 & \\
$\quad \begin{array}{c}\text { Time } \\
(\min .)\end{array}$ & 5 & 0.45 & 0.45 & 3 & 10 & \\
\hline
\end{tabular}




\section{Laser treatment}

Six weeks old plants were transferred by their pots from the green house and placed over night in a dark room to prevent any light exposure the day before treatment. The second uppermost fully expanded leaf of Jatropha curcas plant was irradiated with a continuous wave $10 \mathrm{~mW}$ He-Ne laser (wave length $=632.8 \mathrm{~nm}$ and beam diameter $=5 \mathrm{~cm})$. All other leaves, except those that were treated, were carefully covered with aluminum foil to avoid any background dissipation in our experiment. Laser beam was adjusted to totally cover the surface of the treated leaf. The laser energy was determined at the leaf surface in a power: area ration using a power meter device (Quantel, France). The experiment was done in triplicates, each at a time. Leaf tissues were collected as discs using sterile cork porer after 0 , 1 and $24 \mathrm{~h}$ post-irradiation to compare short term laser effect with respect to the untreated control. Fresh tissues were tested for plant pigments and amino acids at the same day. Tissues collected for chloroplast ultrastructure were fixed immediately in carnoy solution over night then washed three times and stored in $70 \%$ ethanol at $4{ }^{\circ} \mathrm{C}$ until examined.

\section{Laser parameters}

A Helium-Neon (He-Ne) laser ( model of the devise) with an average power density of $10 \mathrm{~mW}$ $\mathrm{cm}^{-2}$ and wave length of $632.8 \mathrm{~nm}$ was used to apply a dose of $300 \mathrm{mJcm}^{-2}$.

\section{Determination of different pigments}

Equal sizes of leaf discs were boiled for 2 min then immersed in absolute ethanol (wt/vol). The leaf tissue was ground with a plastic tip and incubated at room temperature for $3 \mathrm{~h}$ to extract the chlorophyll pigments. The mixture was centrifuged at $5000 \mathrm{rpm}$ for $5 \mathrm{~min}$ to sediment the debris. The absorbance of the clear lysate was measured at 663, 647, 537 and $470 \mathrm{~nm}$. Different plant pigments were determined according to the following equations:

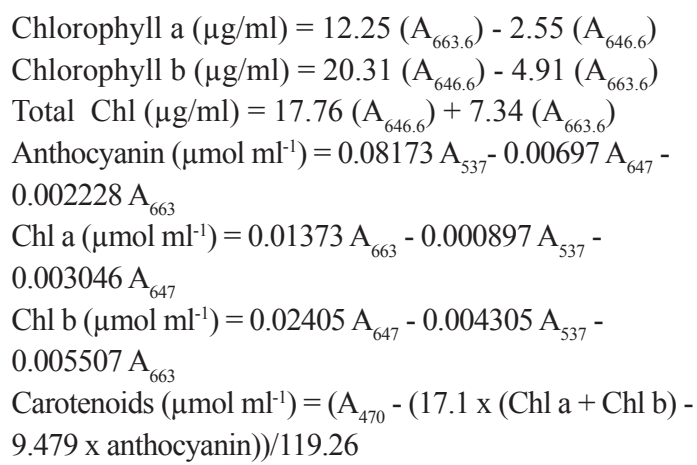

\section{Plastid analysis}

The number of plastids was determined from the TEM micrographs of treated and untreated leaves using the image processing and analysis in Java (Image J) program proimage (Schneider et al., 2012).

\section{Determination of free amino acids by amino} acid analyzer

$0.1 \mathrm{~g}$ of leaf tissue was hydrolyzed with 10 $\mathrm{ml} 6 \mathrm{~N} \mathrm{HCl}$ in a sealed tube according to Bailey $\&$ Sanger (1951). The solution was frozen and evacuated with a vacuum pump (approximately $6.5 \mathrm{~Pa}(0.01 \mathrm{mbar})$. The hydrolysis tube was then closed by melting the glass with a suitable gas burner and hydrolyzed in an oven with a uniform temperature distribution of $110^{\circ} \mathrm{C}$ for $24 \mathrm{~h}$ (in order to create well reproducible hydrolysis conditions) where an oven with air circulation is recommend. The tube was cooled down in an ice-bath after hydrolysis. Afterwards, the solution was centrifuged in order to precipitate insoluble components. The supernatant of the centrifuged solution was taken and evaporated at approximately $40^{\circ} \mathrm{C}$ in a rotary evaporator, and then dissolved with approximately $1 \mathrm{ml}$ distilled water and evaporated once again in order to remove acid traces. The sample was dissolved with 1-2 ml of the sample-diluting buffer. The sample was then ready for analysis with LC 3000 amino acid analyzer (Eppendorff, Germany) under the following conditions: flow rate; $0.2 \mathrm{ml} /$ minute, pressure of buffer: 0 to 50 bar, pressure of Reagent: 0 to 150 bar at $123^{\circ} \mathrm{C}$.

\section{Transmission electron microscopy}

Stained sections were examined with a JEOL 1010 Transmission Electron Microscope (TEM) at the Regional Center for Mycology and Biotechnology (RCMB), Al-Azhar University. Lead acetate at high $\mathrm{pH}$ staining technique was followed according to Reynolds (1963).

\section{Results}

DNA homogenousity in Jatropha curcas plants

All leaf samples of the plants grown from seeds collected from different regions in Egypt were subjected to analysis at the DNA level, using the primers shown in Table 1. All samples were proved to exhibit homogenous DNA and gave identical banding patterns. DNA banding patterns using two primer pairs is shown as an example in Fig.1. 


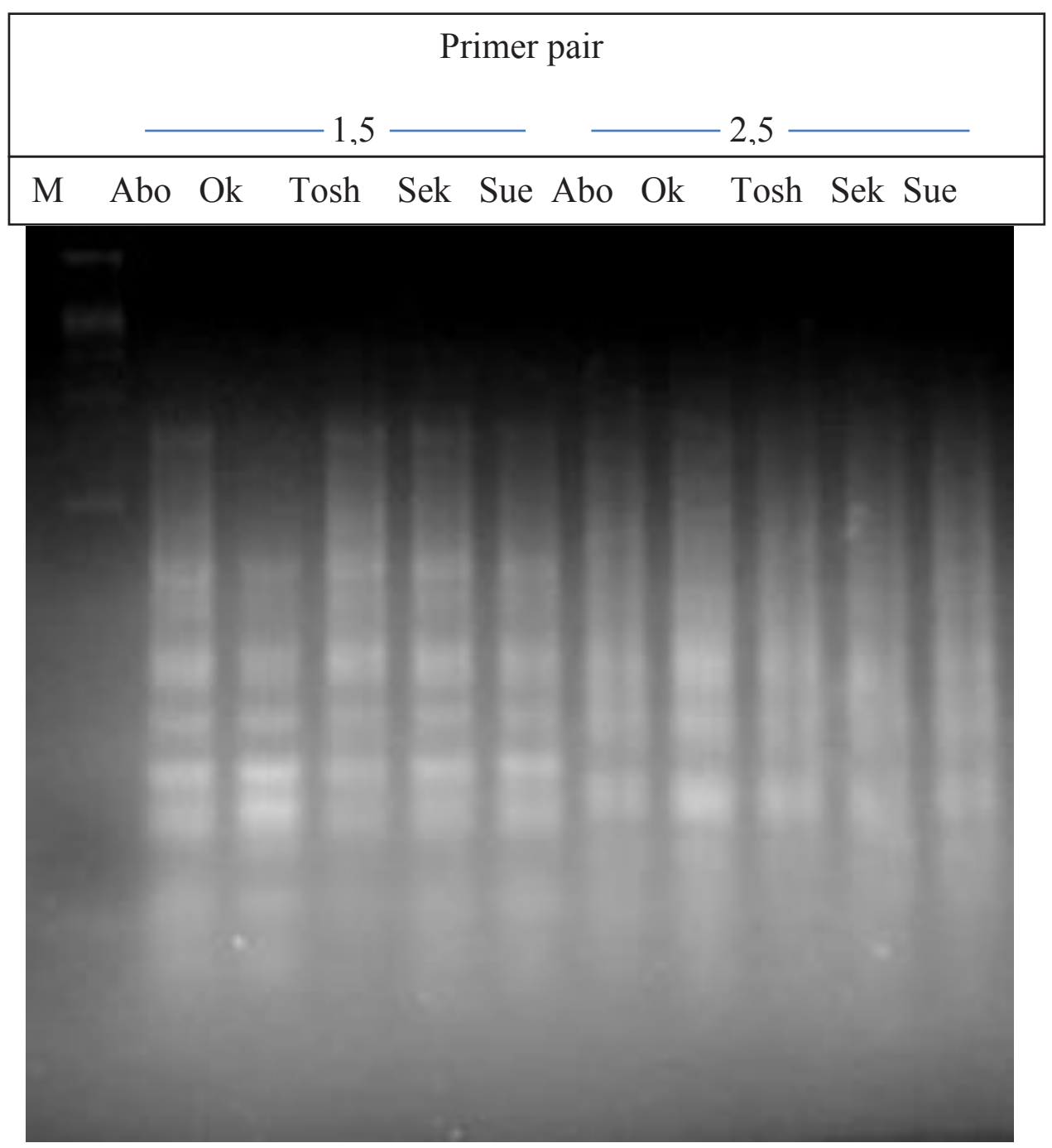

Fig. 1. Representative image showing the identical DNA patterns of Jatropha plants collected from different regions around Egypt using two different pairs of RAPD primers. Marker (M); AboRawash (Abo.); Oksur (OK.); Toshka (Tosh.); Sekem (Sek.) and Suez (Sue.).

Effect of laser irradiation on chloroplast biogenesis and cell morphology of leaves

Laser irradiation resulted in a significant increase in chloroplast number and starch bodies after $24 \mathrm{~h}$ treatment, as compared with the control (Fig. 2, Table 4 ). Figure 3A shows that the chloroplast of $J$. curcas leaves are generally oval in shape and contains 1-2 starch bodies at the most. Chloroplasts start to elongate at 0 and one hours after treatment and this elongation was associated with slight expansion of starch bodies ( Fig 3: B, C, respectively). After $24 \mathrm{~h}$, the chloroplasts retained their oval shape with exhibiting 4 or more starch bodies (Fig. 3 D). New chloroplasts initiated budding process one hour after irradiation (Fig. 4). Moreover, the laser treatment led to increased cell wall thickness (Fig. 5).

\section{Photosynthetic pigments}

Laser irradiation resulted in an increase in the expression of all exanmined plant photosynthetic pigments. As shown in Table 5, including total chlorophylls content was enhanced to (23.47 $\mathrm{mg} / \mathrm{g}$ ), compared to the basal level in the control $(20.80 \mathrm{mg} / \mathrm{g})$;. Carotenoids content amound was also increased from $765.15 \mathrm{mg} / \mathrm{g}$ in the control to $877.43 \mathrm{mg} / \mathrm{g}$ in leaves of the plants irradiated with $300 \mathrm{~mJ}$ laser and analysed $24 \mathrm{~h}$ later (Table 5). 

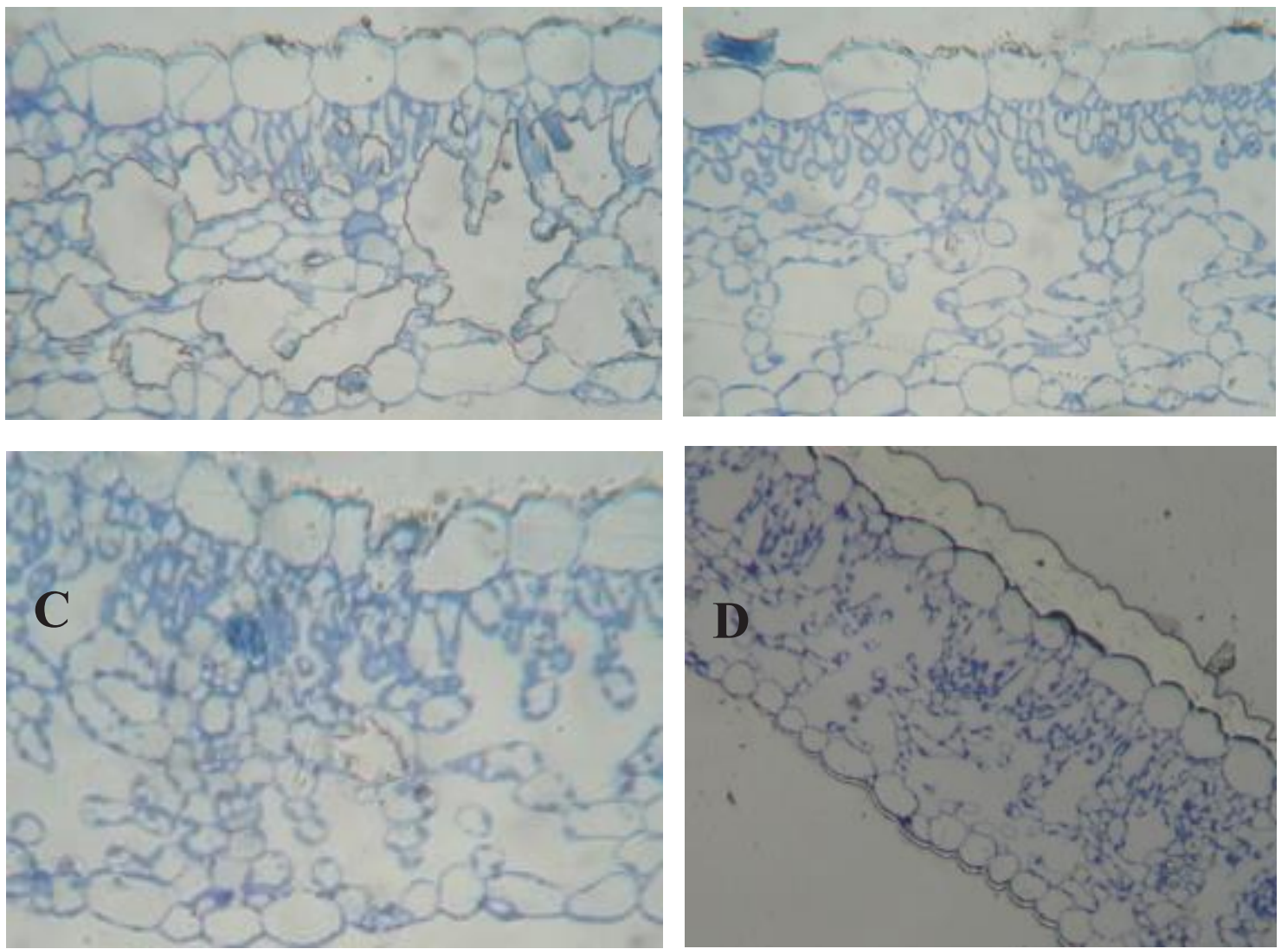

Fig. 2. Representative light micrographs showing T.S section of treated $J$. curcas leaves. Laser irradiation increased the chloroplast number after irradiation. (A): untreated control; (B): $0 \mathrm{~h}$ post irradiation; ( $\mathrm{C}$ ): $1 \mathrm{~h}$ post irradiation; (D): $24 \mathrm{~h}$ post irradiation. Note the increase in chloroplast number after $24 \mathrm{~h}$ treatment.

TABLE 4. Total number of chloroplasrt 24 hrs after irradiations compared with untreated plants.

Total number of chloroplast /cell

Untreated plants

(Control)

$24 \mathrm{~h}$ after $300 \mathrm{~mJ}$ laser

treatment
$3.3 \pm 1.5$

$5.3 \pm 1.6$

\section{Amino acid contents}

All amino acids contents were mostly reduced immediately after irradiation $(0 \mathrm{~h})$ then elevated above their basal level after $24 \mathrm{~h}$ (Table 6). However, the contents of alanine, arginine, tyrosine and phenyle alanine were lower after $24 \mathrm{~h}$, as compared with the untreated control. Interestingly, glutamate increased from $2.4 \mathrm{mg} / \mathrm{g}$ in the untreated control to $33.1 \mathrm{mg} / \mathrm{g}$ right after laser irradiation and then was reduced to 5.14 and $3.37 \mathrm{mg} / \mathrm{g} 1 \& 24 \mathrm{hrs}$ post irradiation (Table
6). Ammonia $\left(\mathrm{NH}_{4}\right)$ also followed the same scenario of glutamate where it increased from $6.05 \mathrm{mg} / \mathrm{g}$ in the control to $38.92 \mathrm{mg} / \mathrm{g}$ at $0 \mathrm{~h}$ after irradiation then decreased to 12.77 and $6.92 \mathrm{mg} / \mathrm{g}$, respectively after 1 and $24 \mathrm{~h}$ after irradiation (Table 6). On contrary, proline concentration was $5.52 \mathrm{mg} / \mathrm{g}$ in the untreated plants, then dropped to undetectable level right after irradiation, and then increased to $11.66 \& 11.76 \mathrm{mg} / \mathrm{g} 1 \& 24 \mathrm{~h}$ after treatment, respectively (Table 6). 

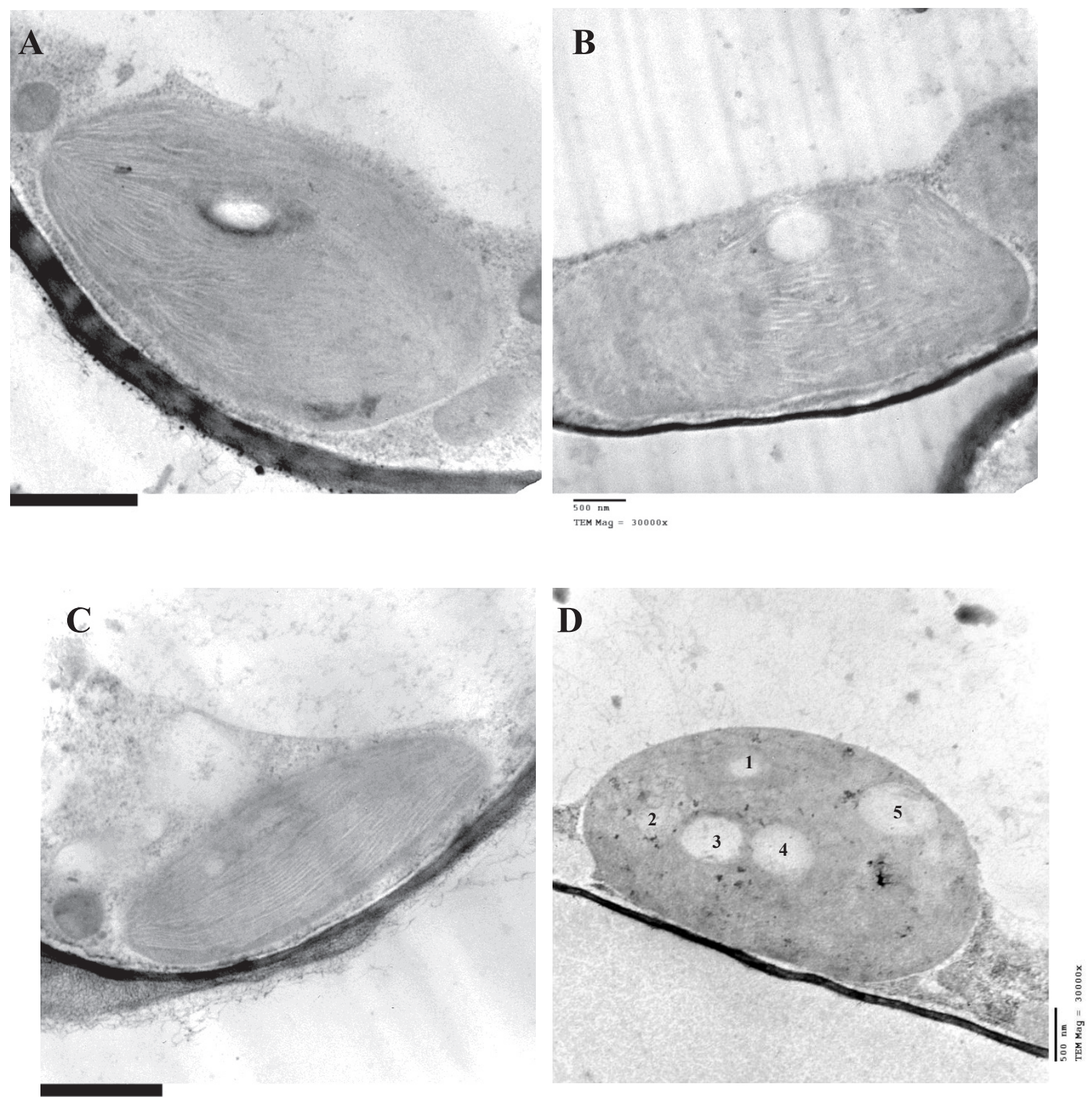

Fig. 3. Representative TEM micrographs showing the ultrastructure of chloroplast in untreated control cells (A); $0 \mathrm{~h}$ post irradiation (B); 1 h post irradiation (C); 24 h post-irradiation (D). Bar=500 $\mathrm{nm}$. 

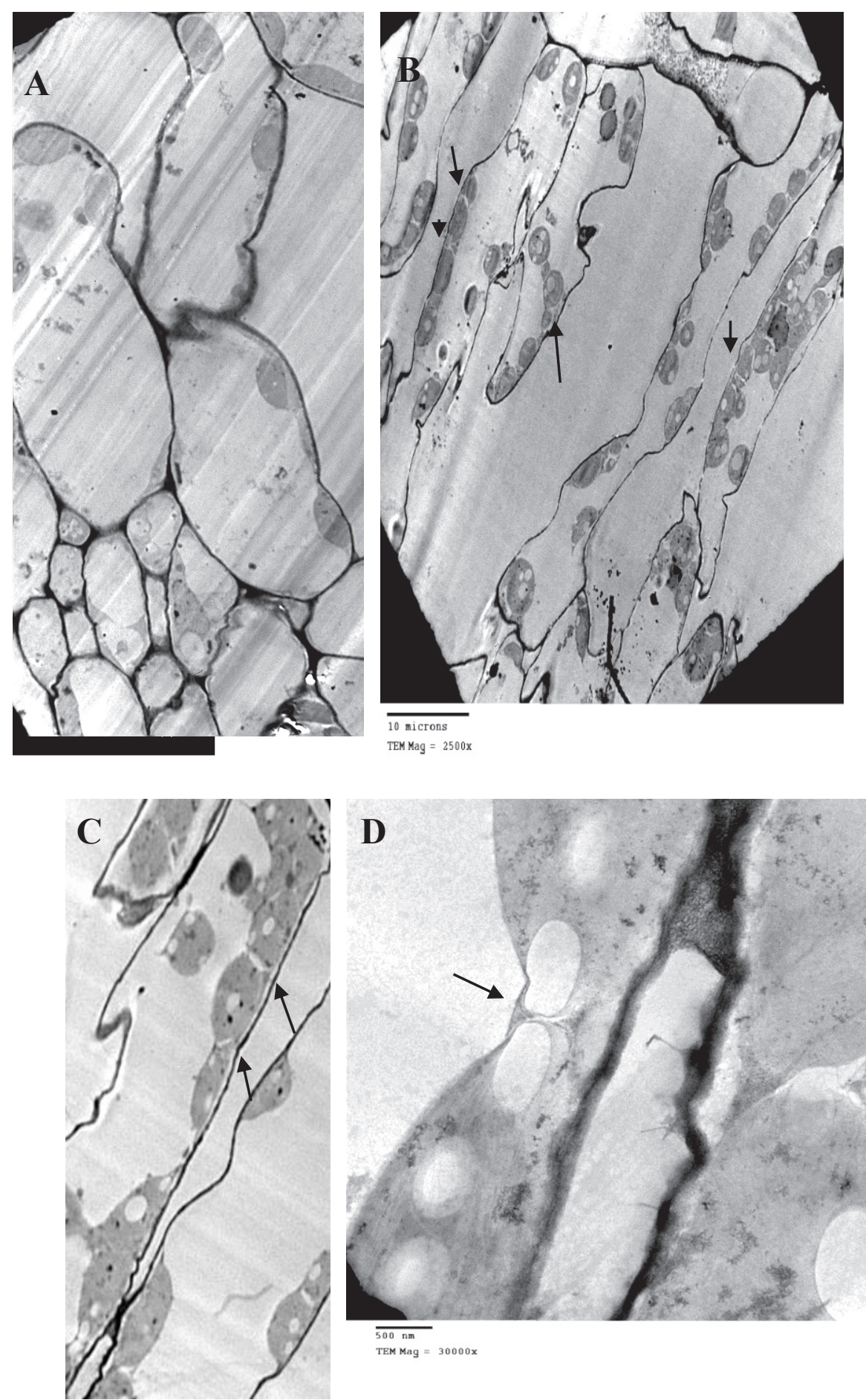

Fig. 4. TEM micrographs showing chloroplast in control plants (A) and in plants treated with $300 \mathrm{~mJ} H e-N e$ laser $24 \mathrm{~h}$ after irradiation (B-D). Note the overall increase in chloroplast number after laser treatment (B) compared with controls (A). Note also the presence of binary fission constriction separating newly dividing chloroplasts as depicted by arrows. A chloroplast act of division is captured at higher magnification in micrograph D. magnification bars $=10 \mu \mathrm{m}$ in $A$ and $B, 500 \mathrm{~nm}$ in $C$ and $D$. 


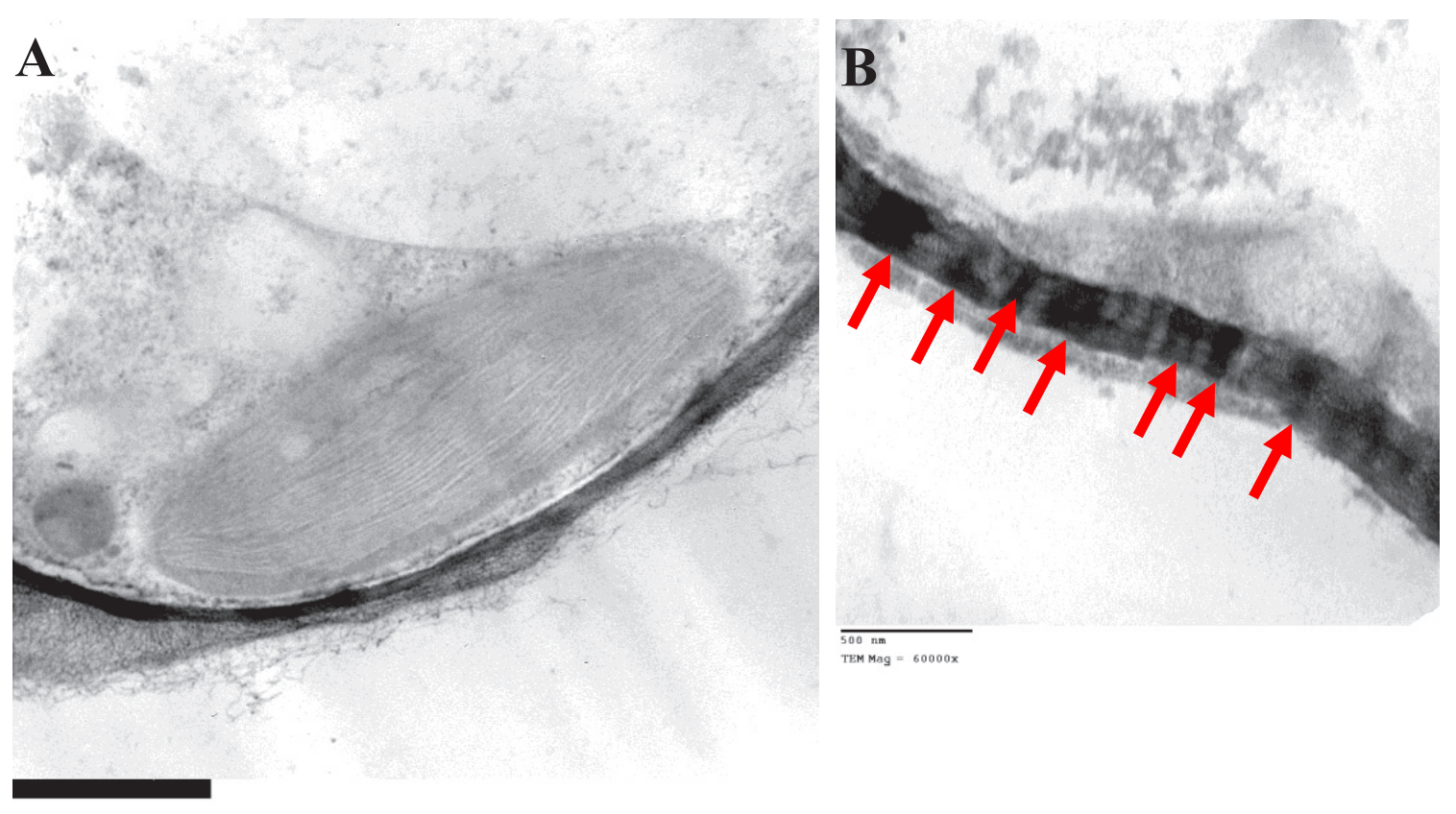

Fig. 5. Representative TEM micrographs showing cell wall thickness before (A) and $24 \mathrm{~h}$ (B) after laser irradiation. Bar $=500 \mathrm{~nm}$. Note the presence of dense dark colored bands in B as depicted by red arrows.

TABLE 5.Concentration of plant pigments in $\mathrm{mg} / \mathrm{ml}$.

\begin{tabular}{lccccc}
\hline $\begin{array}{l}\text { Plant } \\
\text { pigment }\end{array}$ & Cha & Chb & Ch total & Carotenoids & Anthocyanin \\
\hline Cont 0 time & 25.83 & 11.49966 & 17.86464 & 647.7831002 & 0.00487267 \\
& & & & & \\
Cont $24 \mathrm{~h}$ & 30.73 & 13.46366 & 20.80064 & 765.1524788 & 0.00609079 \\
& & & & & \\
0 & 18.785 & 8.18452 & 12.62008 & 470.6316835 & 0.003707143 \\
$1 \mathrm{~h}$ & 16.7175 & 7.232985 & 11.12544 & 419.0084532 & 0.003387305 \\
& & & & & \\
$24 \mathrm{~h}$ & 35.47666667 & 15.28430333 & 23.47421333 & 877.4363531 & 0.00703697 \\
\hline
\end{tabular}


TABLE 6. Distribution of various amino acids dueing the course of laser treatment .

\begin{tabular}{|c|c|c|c|c|}
\hline & $\begin{array}{c}\text { Control } \\
\text { C }\end{array}$ & $\begin{array}{c}\text { Immediatly after } \\
\text { treatment } \\
\text { A }\end{array}$ & $\begin{array}{c}1 \mathrm{~h} \\
\mathbf{B}\end{array}$ & $\begin{array}{c}24 \mathrm{~h} \text { after treatment } \\
\text { D }\end{array}$ \\
\hline Alanine & 2.289795918 & 5.368209256 & 4.833230769 & 1.424587156 \\
\hline Arginine & 0.911953353 & 1.41167002 & 1.924923077 & 0.529908257 \\
\hline Aspartic & 2.443731778 & 4.761368209 & 5.158153846 & 3.495779817 \\
\hline Cystin & 0 & 1.947686117 & 0 & 0 \\
\hline Glutamic & 2.437317784 & 33.10100604 & 5.144615385 & 3.374678899 \\
\hline Glycine & 0.61516035 & 0.748490946 & 1.298461538 & 0.361100917 \\
\hline Histidine & 1.206413994 & 2.258350101 & 2.546461538 & 0.883669725 \\
\hline Isoleucine & 0.528279883 & 1.326358149 & 1.115076923 & 0.686972477 \\
\hline Leucine & 1.141107872 & 2.259959759 & 2.408615385 & 1.853211009 \\
\hline Lysine & 0.541107872 & 1.667605634 & 1.142153846 & 2.012477064 \\
\hline Methionine & 0.916618076 & 1.831790744 & 1.934769231 & 1.374678899 \\
\hline Phenyalanine & 2.662390671 & 3.13722334 & 5.619692308 & 1.726238532 \\
\hline Proline & 5.524781341 & 0 & 11.66153846 & 11.75633028 \\
\hline Serine & 0.867055394 & 2.169818913 & 1.830153846 & 3.424587156 \\
\hline Threonine & 1.620408163 & 2.313078471 & 3.420307692 & 1.065688073 \\
\hline Tyrosine & 7.023323615 & 6.511066398 & 14.82461538 & 4.372844037 \\
\hline Valine & 0.315451895 & 0.635814889 & 0.665846154 & 1.111192661 \\
\hline NH4 & 6.050145773 & 38.91991952 & 12.77046154 & 6.924770642 \\
\hline
\end{tabular}

The final concentration of each amino acid is calculated in $\mathrm{mg} / \mathrm{g}$

\section{Discussion}

Analysis of DNA in $J$. curcas leaf samples of the plants grown from seeds obtained from five different localities in Egypt confirmed their homogenousity (Fig. 1). Laser treatment was applied to 6-week-old plants where leaves were fully expanded. In this connection, laser treatment had long been proven as an efficient way to accelerate plant germination, growth and development (Khalifa \& Ghandoor, 2011;
Perveen et al., 2011; Khalifa \& Elsherief, 2013 and Chen et al., 2014). Laser effect could be attributed to light electromagnetism and enhanced temperature and/ or due to photochemical effect on one or more key factors inside the cell (Fodor et al., 2011). Generally, laser treatments can be categorized into stimulatory and destructive. Stimulatory doses likely lie in the range of 100 $-500 \mathrm{~mJ}$ for living cells, but above $600 \mathrm{~mJ}$, laser is considered destructive due to irreversible lethal effect (Zungu et al., 2009). Thus, in our 
work we applied a dose equaling $300 \mathrm{~mJ} \mathrm{~cm}^{-2}$ Helium-Neon $(\mathrm{He}-\mathrm{Ne})$ laser, that is considered stimulatory. It should be noted that this was previously confirmed the work done by Khalifa \& Ghandoor (2011) and Khalifa and Elsherief (2013). This could be further reinforced by the results of Perveen et al. (2011), where $300 \mathrm{~mJ} \mathrm{He}-$ Ne laser treatment resulted in the best results in enhancing the level of antioxidant enzymes and those of phosphorous and nitrogen in Helianthus annuus.

In general, laser treated plants showed various changes in growth and biochemical parameters. Many reports stated that appropriate laser dose could result in pronounced positive effects on seed germination, growth parameters, the number of branches per plant total biomass, leaf area, growth rate, seed emergence, root length, shoot length, and crop yield (Perveen et al., 2011). Laser enhanced chlorophylls a, $\mathrm{b}$, and $\mathrm{a} / \mathrm{b}$ ratio (Cholakov \& Petkova, 2002) and consequently increased photosynthetic rate (Rybinki \& Garzynski, 2004). In addition, laser could enhance the mineral profile content of $\mathrm{P}$ and $\mathrm{N}$ in treated plants (El-Tobgy et al., 2009). In spite of the conclusions mentioned above, not much is known yet about the mechanism by which the beneficial effect of laser is attained at the molecular level. Therefore, from the point of view of molecular genetics of plant development, we drew our attention to possible effects of the given laser treatment (short term effect of $300 \mathrm{~mJ}$ He-Ne laser) on chloroplast biogenesis, leaf cell characteristics and concomitant photosynthetic pigment and amino acid contents of Jatropha curcas leaves. The changes that occurred in the treated cells $(0,1$ and $24 \mathrm{~h}$ post-irradiation) were monitored at 0,1 and $24 \mathrm{~h}$ post-irradiation. Chloroplasts are the primary photoreceptors in plants. To date, the prospects regulating the crucial function of chloroplast are unraveled and still need further investigation (Pogson et al., 2015). Thus, this study aimed to determine short term effect of $300 \mathrm{~mJ} \mathrm{He}-\mathrm{Ne}$ laser on the cytology of treated cells focusing on chloroplast ultrastructure, plant pigmentation and the content of different amino acids after treatment. Changes occurred in the treated cells ( 0,1 and $24 \mathrm{~h}$ post-irradiation) were monitored in terms of leaf morphology, plastid number, chloroplast ultrastructure, pigment content and the levels of total free amino acids with respect to the untreated control plants. Our results showed that the applied treatment enhanced plant branching which is observed 2 weeks postirradiation (our unpublished data). Plant tissues analyzed immediately after treatment or one hour after treatment showed reduction in the amount of plant photosynthetic pigments in relation to the untreated control (Table 1). However, the increase in chloroplast number (Table 3 and Fig. $2,4)$, counts of starch body $24 \mathrm{~h}$ after irradiation (Fig. 3) as well as the concomitant enhanced contents of photosynthetic pigments and amino acids (Tables 5,6, respectively) could be assumed to indicate the efficiency of laser in these respects. In general, chloroplast division is reported in land plants and found to be unsynchronized with the division of the host cells (Okazaki et al., 2010). The chloroplast division rate was shown to be regulated by the plastid division (PDV) protein that is present in almost all land plants (Okazaki et al., 2010). In our research, laser seemed to encourage a trend of upregulated chloroplast division by yet undetermined mechanisms (Fig. 4 and Table 4). As laser is a strong light beam, thus it was expected to see some sort of stress response upon laser perception by our treated plants. Chloroplast repositioning was reported as an adaptive mechanism during stress conditions (Wada \& Suetsugu, 2004 and Samardakiewicz et al., 2015). In our work, chloroplast relocation was observed at 0 and one hour post irradiation and then was re-adjusted $24 \mathrm{~h}$ post irradiation to normal position as was in the control. It had been also reported that chloroplasts migrated toward nuclear cytoplasm in case of blue laser while, toward cortical cytoplasm, in response to green laser in Pleurosira leavis (Shihira-Ishikawa et al., 2007).

Chlorplast, as an organell, can synthesize a number of amino acids during the process of photosynthesis. Interestingly, chloroplast is able to synthesize all protein forming amino acids except leucine (Kirk \& Leech, 1972). Soluble amino acids that are rapidly transported to growing root and shoots are those with a high $\mathrm{N}$ : C ratio such as asparagine, glutamine, and arginine (Lea et al., 2007). Glutamine, asparagine, glutamate and aspartate are the major amino acids in leaves and roots and are transported in the vascular tissues to control the nitrogen status during growth and development (Pate \& Layzell, 1990). The main pathway of glutamate is shown in Fig. 6.Glutamate is the most abundant amino acid formed by chloroplast followed by aspartate and threonine (Kirk \& Leech, 1972). Glutamate is the precursor for chlorophyll synthesis in developing leaves (Yaronskaya et al., 2006), is crucial signaling molecule (Forde, 2002), is tightly regulated by light (Coschigano et al., 1998) via a phytochrome-mediated pathway (Suzuki et al., 2001) and is directly involved in the assimilation and dissimilation of ammonia (Weber \& Flügge, 2002). Ammonium ion is the 
final form of inorganic nitrogen and represents the source of nitrogen present in all organic nitrogen compounds such as amino acids and nucleic acids (von Wirén et al., 2000). Aspartate and alanine then provide the nitrogen required for the formation of other amino acids. Our results indicated that glutamate basal level was 2.43 $\mathrm{mg} / \mathrm{g}$ in the control then was over expressed right after laser treatment $(33.10 \mathrm{mg} / \mathrm{g})$ and then started to decreased gradually to 5.14 and $3.37 \mathrm{mg} / \mathrm{g}$ one and $24 \mathrm{~h}$ after treatment, respectively. Since these changes were accompanied by correspondingly elevated chlophylls, this might indicate increased incorporation rates of glutamate into chlorophylls after one and $24 \mathrm{~h}$ laser treatments. A similar trend was shown by ammonia that might be assimilated into newly synthesized proteins during the $24 \mathrm{~h}$ period after treatment. The increase of ammonia immediately after irradiation might be resulted from photorespiration (Leegood et al., 1995). Glutamate is also central for the synthesis of arginine and proline as shown in Fig. 6 (Forde \& Lea, 2007). Interestingly, Arginin level was more or less constant during the whole course of treatment while proline was depressed right after treatment then elevated above its basal level 24 $\mathrm{h}$ post-irradiation. Thus, laser treatment seems to influence a shift in glutamate pathway toward proline formation (Fig. 6, Tables 1, 3). The amino acid proline is associated with environmental stresses (Ashraf \& Foolad 2007 and Fichman et al., 2015). Plants engineered to accumulate proline exhibit the ability to tolerate salinity, oxidative and drought stress (Hong et al., 2000). Proline has strong influence on plant developmental processes including cell division, embryo development, and flowering (Mattioli et al., 2008). It also promotes the formation of proline-rich cell wall linker proteins in the plasmalemma that are responsible for cell wall maintenance and stress-induced fortification (Stein et al., 2011). This conclusion might be linked with our present work results where laser resulted in increasing the cell wall thickening in the plants examined $24 \mathrm{~h}$ after irradiation, as compared to their untreated control (Fig. 5). Phenolic compounds accumulation was also observed in the cytoplasm of the treated cells after $24 \mathrm{~h}$ post-irradiation (Fig. 3). This might verify the function of phenolic compounds as a mechanism that plants usually use as sunscreen for protection against strong light. Our overall data strongly support that laser as a strong light signal can induce enhanced chloroplast biogenesis and amino acid biosynthesis, as well as elevation of photosynthetic pigment contents in the irradiated plants.

\section{Forde and Lea}

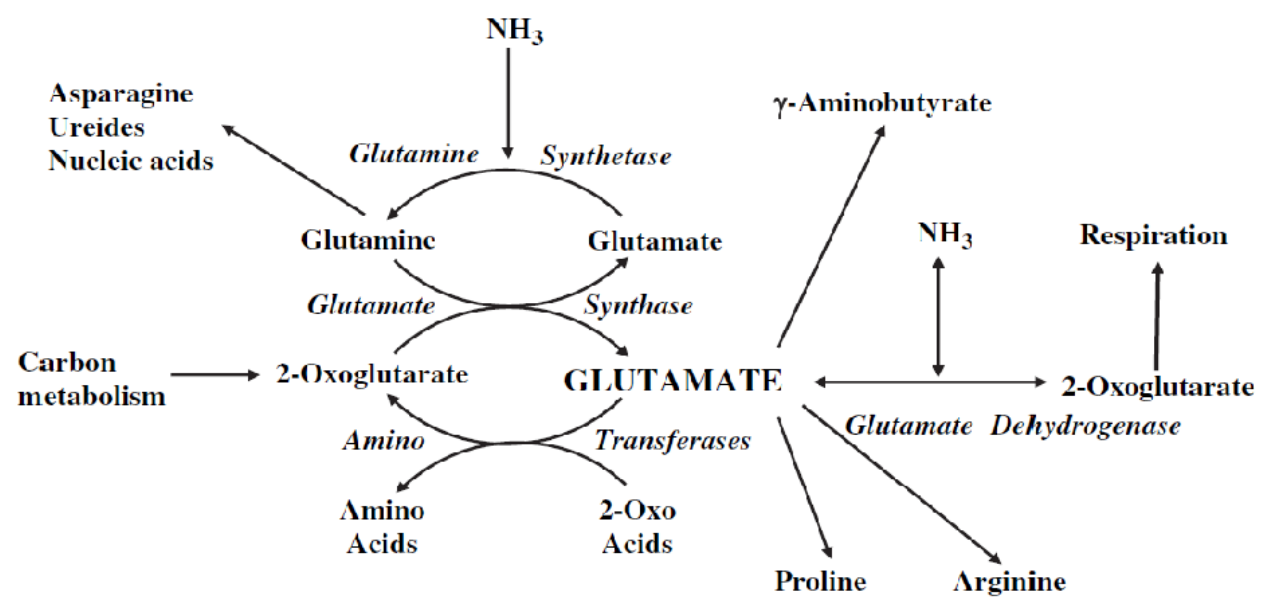

Fig. 6. Pathway of Glutamate, proline, Arginine, Asparagine and Ammonia in higher plants according to Forde \& Lea (2007). 


\section{Conclusion}

Laser as a strong light signal promotes the biogenesis of chloroplast more likely via the enhanced assimilation of amino acids that is involved in their induction. Chloroplast biogenesis could be further supported by the increase in their stored starch and the elevation in their plant pigment contents after laser treatment. In addition, the conversion of glutamate into proline as indicated by our results could refer to the importance of laser to induce proline biosynthesis in plants. This could be supported in part by the increase in the wall thickness of leaf cells $24 \mathrm{~h}$ after laser irradiation that might be attributed to the increase of proline rich regions in the cell wall. However, further study is needed to determine if the results obtained in the present work will lead to increased oil production in Jatropha curcas as a promising oil producing plant.

\section{Reference}

Ashraf, M. and Foolad, M.R. (2007) Roles of glycine betaine and proline in improving plant abiotic stress resistance. Environ Exp Bot. 59, 206-216. doi: 10.1016/j.envexpbot.2005.12.006

Bailey, K. and Sanger, F. (1951) The chemistry of amino acids and proteins. Annu Rev Biochem. 20,103-130. doi10.1146/annurev.bi.20.070151.000535.

Chao, S., Somers, D. and Warner, P. (2017)Wheat and barley DNA extraction in 96-well plates. Somer Lab Protocols, 1,789-791.

Chen, H., Han, R., Dzhabiev, T.S., Shilov, A.E., Ngo, Q.B., Dao, T.H., Chau Nguyen, H., Hennessy, M. and Hamblin, M.R. (2014) He-Ne laser treatment improves the photosynthetic efficiency of wheat exposed to enhanced UV-B radiation Biomimetic utilization of solar energy, photobiomodulation and the brain: a new paradigm. Laser Physics, 24,10-17.

Coschigano, K.T., Melo-Oliveira, R., Lim, J. and Coruzzi, G.M. (1998) Arabidopsis gls mutants and distinct Fd-GOGAT genes. Implications for photorespiration and primary nitrogen assimilation. The Plant Cell, 10,741-52.

Cholakov, D. and Petkova, V. (2002) Morphological and physiological characterstics of seedlings caused by laser and gamma irradiation of cucumber seeds. Acta Hortic. 579,285-288.

El-Tobgey, M.K., Yasser, A.H., Osman, A.M. and El Sherbini, E.A. (2009) Effect of laser radiation on growth, yield and chemical constituents of anise and cumin plants. Journal of Applied Sciences Research, 5(5), 522-528.

Fichman, Y., Gerdes, S.Y., Kovács, H., Szabados, L., Zilberstein,A. and Csonka, L.N. (2015) Evolution of proline biosynthesis: enzymology, bioinformatics, genetics, and transcriptional regulation. Biol. Rev. 90,1065-1099. doi: 10.1111/brv.12146.

Fodor, L., Ullmann, Y. and Elman, M. (2011) "Aesthetic Applications of Intense Pulsed Light". Ch2: Light Tissue Interaction. Springer Press. Verlage London limited, 11.

Forde, B.G. (2002) Local and long-range signaling pathways to nitrate. Annu. Rev, Plant Biol. 53, 203 224. doi: 10.1146/ annurev.arplant.53.100301.135256.

Forde, B.G. and Lea, P.J. (2007) Glutamate in plants: Metabolism, regulation, and signaling. J. Exp. Bot. 58, 2339-58. doi: 10.1093/jxb/erm121.

Gutteridgel, S. and Gatenby, A.A. (1995) Rubisco synthesis, assembly, mechanism, and regulation. The Plant Cell, 7, 809-819.

Hong, Z., Lakkineni, K., Zhang, Z. and Verma, D.P. (2000) Removal of feedback inhibition of delta(1)pyrroline-5-carboxylate synthetase results in increased proline accumulation and protection of plants from osmotic stress. Plant Physiol. 122,1129-36.

Khalifa, N.S. and El-Sherief, A.F. (2013) Laser preatretment of seeds resulted in the accumulation of some protiens in Jatropha curcas plants as identified by MALDI-TOF analysis. Egyptian Journal of Botany, 10, 30-40.

Khalifa, N.S. and Ghandoor, H. El (2011) Investigate the effect of Nd-Yag laser beam on soybean (Glycin $\max$ ) leaves at the protein level. Int J. Biol. 3(2), 133- 144. doi: 10.5539/ijb.

Kirk, P.R. and Leech, R.M. (1972) Amino acid biosynthesis by isolated chloroplasts during Photosynthesis. Plant Physiol. 50, 228-34.

Lea, P.J., Sodek, L., Parry, M.A.J., Shewry, P.R. and Halford, N.G. (2007) Asparagine in plants. Annals Appl. Biol. 150, 1-26. doi: 10.1111/j.17447348.2006.00104.x

Leegood, R.C., Lea, P.J., Adcock, M.D. and Hausler, R.E.(1995) The regulation and control of photorespiration. J. Exp. Bot. 46,1397-141. dio: 10.1093/jxb/46.special_issue.1397.

Mattioli, R., Marchese, D., D’Angeli, S., Altamura, 
M.M., Costantino, P. and Trovato, M. (2008) Modulation of intracellular proline levels affects flowering time and inflorescence architecture in Arabidopsis. Plant Mol. Biol. 66,277-288. doi: 10.1007/s11103-007-9269-1.

Montes, J.M. and Melchinger, A.E. (2016) Domestication and breeding of Jatropha curcas L. Trends Plant Sci. 21,1045-1057.

Okazaki, K., Kabeya, Y. and Miyagishima, S. (2010) The evolution of the regulatory mechanism of chloroplast division. Plant Signal Behav. 5,164-7.

Openshaw, K. (2000) A review of Jatropha curcas: An oil plant of unfulfilled promise. Biomass and Bioenergy, 19,1-15. doi: 10.1016/ S0961-9534 (00) 00019-2.

Pate, J. S. and Layzell, D. B. (1990) Energetics and biological costs of nitrogen assimilation. Biochem. Plants, 16, 1-42.

Perveen, R., Jamil ,Y., Ashraf, M., Ali, Q., Iqbal, M. and Ahmad, M.R. (2011) He-Ne laser-induced improvement in biochemical, physiological, growth and yield characteristics in sunflower (Helianthus annuus L.). Photochem Photobiol. 87,1453-63. doi: 10.1111/j.1751-1097. 2011. 00974.x.

Pogson, B.J., Ganguly, D. and Albrecht-Borth, V. (2015) Insights into chloroplast biogenesis and development. Biochim Biophys Acta (BBA)Bioenergetics, 1847,1017-1024. doi: 10.1016/j. bbabio.2015.02.003.

Reynolds, E.S. (1963) The use of lead citrate at high $\mathrm{pH}$ as an electron-opaque stain in electron microscopy. J.Cell Biol. 17,208-12.

Rybiñski, W. and Garczyñski, S. (2004) Influence of laser light on leaf area and parameters of photosynthetic activity in DH lines of spring barley (Hordeum vulgare L.). Int. Agrophys. 18,261-267.

Sakamoto, W., Miyagishima, S.Y. and Jarvis, P. (2008) "Chloroplast Biogenesis: Control of Plastid Development, Protein Import, Division and Inheritance". Arabidopsis Book. 6:e0110.

Samardakiewicz, S., Krzeszowiec-Jeleń, W., Bednarski, W., Jankowski, A., Suski, S., Gabryś, H. and Woźny, A. (2015) Pb-Induced avoidance-like chloroplast movements in fronds of Lemna trisulca L. PLOS ONE, 10, e0116757. doi: 10.1371/journal. pone. 0116757 .

Schneider, C.A., Rasband, W.S. and Eliceiri, K.W. (2012)NIH image to image J: 25 years of image analysis. Nature methods. doi: 10.1038/nmeth.2089.

Shihira-Ishikawa, I., Nakamura, T., Higashi, S. and Watanabe, M. (2007) Distinct responses of chloroplasts to blue and green laser microbeam irradiations in the centric diatom Pleurosira laevis. Photochem. Photobiol. 83,1101-1109. doi: 10.1111/j.1751-1097.2007.00167.x

Stein, H., Honig, A., Miller, G., Erster, O., Eilenberg, H., Csonka, L.N., Szabados, L., Koncz, C. and Zilberstein, A. (2011) Elevation of free proline and proline-rich protein levels by simultaneous manipulations of proline biosynthesis and degradation in plants. Plant Sci. 181,140-150. doi: 10.1016/j.plantsci.2011.04.013

Suzuki, A., Rioual, S., Lemarchand, S., Godfroy, N., Roux, Y., Boutin, J.P. and Rothstein, S. (2001) Regulation by light and metabolites of ferredoxindependent glutamate synthase in maize. Physiol. Plant, 112, 524-530. doi: 10.1034/j.13993054.2001.1120409.x.

Von Wirén, N., Gazzarrini, S., Gojon, A. and Frommer, W.B. (2000) The molecular physiology of ammonium uptake and retrieval. Curr. Opin. Plant Biol. 3, 254-261. doi: 10.1016/S1369. 5266(00)80074-6.

Wada, M. and Suetsugu, N. (2004) Plant organelle positioning. Curr. Opin. Plant Biol. 7, 626-631. doi: 10.1016/j.pbi.2004.09.005.

Weber, A. and Flügge, U. (2002) Interaction of cytosolic and plastidic nitrogen metabolism in plants. J. Exp. Bot. 53, 865-874. doi: 10.1093/jexbot/53.370.865.

Xiaoling, G. A. O.,Yingsen, H.E. and Xiaoyan, X.U. (2013) Laser - effects of laser and enhanced UV-B radiation on photosynthesis of peanut seedlings. $J$ Guizhou Agr. Sci. 2,4-7.

Yaronskaya, E., Vershilovskaya, I., Poers, Y., Alawady, A.E., Averina, N. and Grimm, B. (2006) Cytokinin effects on tetrapyrrole biosynthesis and photosynthetic activity in barley seedlings. Planta, 224, 700-709. doi: 10.1007/s00425-006-0249-5.

Zungu, I.L., Hawkins, D. and Abrahamse, H. (2009) Mitochondrial responses of normal and injured human skin fibroblasts following low level laser irradiation--an in vitro study. Photochem. Photobiol. 85, 987-996. 


\title{
التاثير قصير الأجل لليزرمن نوع غاز الهيليوم والنيون على نماء الاوراق وتصنيع الأحماض الامينيه فى

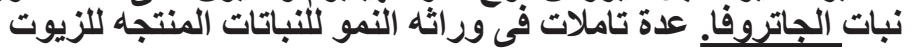

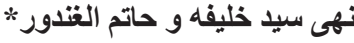 \\ قسم النبات ـ وحدة الخليه و الور اثثة و *قسم الفيزياء ـ وحدة فيزياء الليزر ـ كليه العلوم - جامعة عين شمس ـ القاهرة ـ مصر.
}

\begin{abstract}
إن الجاتروفا نبات واعد لانتاج زيت البيوديزل الحيوي. ويعد استخدام طرق فيزيائيه غير تقليدية كالليزر لزيادة انتاجيه النبات

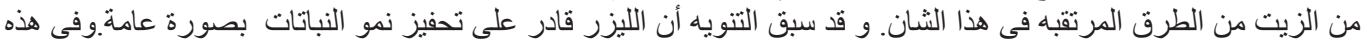

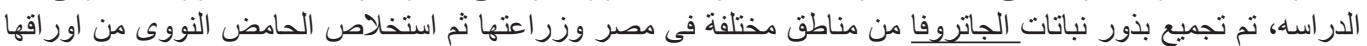

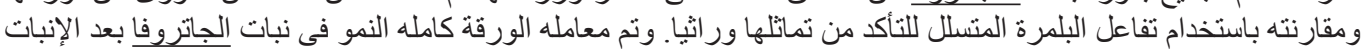

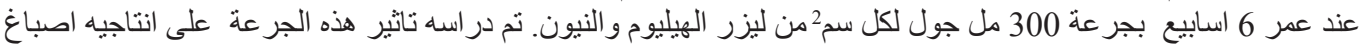

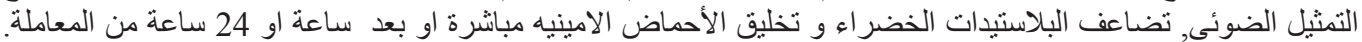

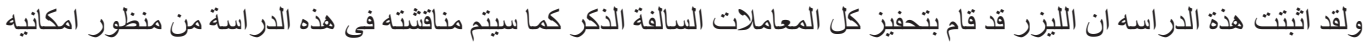

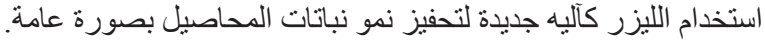

